\title{
Development of a Comprehensive Modeling System for Assessing Impact of Temporally and Spatially Changing BMP
}

\author{
시·공간적으로 변화하는 최적관리기법 평가를 위한 통합모형시스템 개발
}

\author{
Cho, Jaepil ${ }^{*}$ Chun, Jong Ahn ${ }^{* *+} \cdot$ Mostaghimi, Saied $^{* * *}$ \\ 조재필 ${ }^{*}$ 전종안 ${ }^{* *+}$ - 모스타기미 사이드**
}

\begin{abstract}
토지이용변화가 수질에 미치는 영향을 평가하기 위하여 비점오염모형이 광범위하게 사용되고 있다. 본 연구에서는 최적관리 기법이 수문 · 수질에 미치는 영향을 평가하기위한 통합모형시스템을 개발하였다. 통합모형시스템은 DANSAT (Dynamic Agricultural Non-point Source Assessment Tool) 과 사용자 인터페이스로 구성되어있다. DANSAT은 분포형 연속 강우사상 모형으로서 농업 소유역에서의 유출량, 유사량, 농약 물질의 이동기작 등을 모의한다. DANSAT은 크게 동적변수 부모형, 수문 부모형, 유사 이동 부모형, 농약 물질 이동 부모형둥 4 개의 부모형으로 구성되어있다. 동적변수 부모형은 토양의 특성, 작물의 생장 및 작물 잔여 물질의 분해 둥을 모의하는 하부모형으로 구성되어있으며, 토지 이용 변화에 관계되는 내부 변수들의 시간적 변화를 모의한다. 수문 부모형은 차단, 중발산량, 침투량, 침루량 둥을 모의하는 격자 단위 프로세스와 지표유출, 중간유출, 기저유출 및 하천에서 의 물의 이동을 모의하는 유역 단위 프로세스로 구성되어있다. 유사 이동 부모형은 세류간 (interrill) 토양입자의 분리, 세류 (rill) 및 하천내의 토양분리, 운송가능량 둥을 모의하며, 농약 물질 이동 부모형은 농약의 분해, 평형, 식물에 의한 흡수, 침출 등을 고려하여 농약 물질의 이동을 모의한다. 입력변수는 최적관리기법의 시·공간적인 변화를 고려할 수 있도록 계층구조로 구성하였 다. 유역출구에서의 결과 출력 뿐만 아니라, 유역전체에 걸쳐 지표면과 지하수면 사이에서 물 및 오염물질의 이동량 분석을 위 한 출력 및 격자단위의 상세 결과 출력을 통하여 최적관리기법을 평가하고 분셕할 수 있다. 한편, 사용자 인터페이스는 모형의 구동을 위해 요구되는 광대한 시·공간 입력 자료를 기존에 존재하는 데이터베이스를 이용하여 생성할 수 있도록 개발되었다.
\end{abstract}

Keywords: Dynamic agricultural nonpoint source assessment tool (DANSAT); model development; best management practices (BMPs); watershed model

\section{INTRODUCTION}

Non-point source (NPS) pollution has been labeled as the most significant source of water quality problems in the United States (USEPA, 2000). In Korea, 22\% to 37\% of total BOD loads are originated from NPS pollution

* USDA-ARS, Southeast Watershed Research Laboratory

** USDA-ARS, Crop Systems and Global Changes Laboratory

*** Biological Systems Engineering Department, Virginia Tech

+ Corresponding author. Tel.: +1-301-504-6633

Fax: +1-301-504-6633

E-mail address: jongahn.chun@ars.usda.gov.

2009년 1월 12일 투고

2009년 1월 30일 심사완료

2009년 3월 17일 게재확정 within the four major river basins (Choi and Shin, 2002). NPS pollution abatement is usually focused on land and runoff management practices because the pollutants are generated over an extensive area of land and enter receiving water bodies in a diffused manner. Best management practices (BMPs) have been used to reduce or remove NPS pollutants which enter receiving waters (Line et al., 1999). However, evaluating impacts of BMPs on hydrology and water quality for a particular condition is difficult mainly due to strong influences by uncontrollable climatic events as well as site-specific characteristics such as soils, topography, and land use (Novotny and Olem, 1994). 
Computer-based modeling has been considered a costeffective tool for evaluating the effect of spatially and temporally changing BMPs because of the advantages in predicting and ranking BMP alternatives prior to their implementation. Deterministic NPS pollution models can be classified into continuous or single-event models depending on the simulated time scale (Borah et al., 2006; Bouraoui and Dillaha, 2000). The continuous simulation NPS models are needed to estimate the long-term effects of land use changes and watershed management practices (Borah and Bera, 2004). Borah and Bera (2003) reviewed frequently used watershed-scale hydrologic and NPS pollution models based on model capability, temporal and spatial representation, mathematical strength, and applicability of hydrology, sediment, chemical, and BMP components. Examples of continuous simulation models include AnnAGNPS (Bingner and Theurer, 2001), ANSWERS-2000 (Bouraoui et al., 2002), HSPF (Bicknell et al., 1993), MIKE-SHE (Refsgaard and Storm, 1995), and SWAT (Arnold et al., 1998). However, HSPF is a semi-distributed model, which limits the capability of the model to simulate the impacts of BMP application in different locations within a subwatershed. HSPF also requires intensive model calibration for simulating significant land use changes because it uses conceptual equations and parameters which are not directly linked to the physical conditions of a watershed (Refsgaard and Knudsen, 1996). Similar to HSPF, AnnAGNPS and SWAT use empirically derived approaches such as curve number $(\mathrm{CN})$ and Universal Soil Loss Equation (USLE) methods for simulating runoff and soil erosion, respectively. The selected methods restrict the capability of the model to simulate spatially and temporally changing BMPs because it is difficult to estimate appropriate $\mathrm{CN}$ values and USLE factors for different BMP scenarios (Bouraoui, 1994; Byne, 2000). As a result, physicallybased and distributed parameter models have advantages in predicting the effectiveness of BMPs (Bouraoui and Dillaha, 1996; Bouraoui and Dillaha, 2000). ANSWERS-2000 and MIKE-SHE are both physically-based and distributed models. However, extensive requirement of input parameters and lack of available data are known to be limiting factors in applying MIKE-SHE (Bouraoui et al., 1997). ANSWERS2000 does not simulate interflow and baseflow contributions to streams (Borah and Bera, 2003) and it may cause difficulty in evaluating the impacts of BMP on subsurface areas and interaction between surface and ground water. As a result, the Dynamic Agricultural Non-point Source Assessment Tool (DANSAT) was developed for evaluating long-term impacts of temporally and spatially changing BMPs on hydrology and water quality at the watershedscale by considering the interaction between surface water and ground water (Cho, 2007).

Distributed and physically-based model, such as DANSAT, has limitations in applying at watershed-scale because of its intensive input data or parameter requirement and difficulties in analyzing the spatial simulated model outputs. Development of a user interface to couple GIS with hydrologic models has been the focus of many studies since the early 1990s (Borah and Bera, 2003). Linkage of GIS and computer simulation models can be classified into these approaches: 1) loose, 2) close, and 3) tight coupling approaches (Tim, 1996). Ogden et al. (2001) summarized representative GIS modules for hydrologic analysis and distributed hydrologic models. A number of GIS interfaces developed for distributed hydrologic and water quality models include AGNPS (He et al., 1993; He et al., 2001; Liao and Tim, 1997; Line et al., 1997; Srinivasan and Engel, 1994), ANSWERS (Engel et al., 1993; Zhang and Hayes, 1999), and ANSWERS2000 (Veith et al., 2000). Accordingly, the objective of this paper is to describe the newly developed comprehensive modeling system, which consists of DANSAT and its user interface for assessing impacts of temporally and spatially changing BMPs.

\section{DANSAT}

\section{Components}

DANSAT was developed to evaluate the spatial and temporal impacts of BMPs on hydrology, sediment, and pesticide losses in agricultural watersheds (Cho, 2007; Cho and Mostaghimi, 2009b, 2009c). DANSAT consists of hydrology, sediment, pesticide, and dynamic variable components and selected methods for each component are described in Table 1. The overall sequence of com- 
Table 1 Methods used in hydrology, sediment, and pesticide components of DANSAT

\begin{tabular}{|c|c|}
\hline Criteria & Description \\
\hline Hydrology & $\begin{array}{l}\text { - Excess rainfall for overland flow is separated based on Green-Ampt equation (Green and Ampt, 1911). } \\
\text { - Potential evapotranspiration is estimated based on Priestly-Taylor method (Priestley and Taylor, 1972). } \\
\text { - } \text { Actual evaporation and transpiration are separately calculated based on Richie's method (Ritchie, 1972). } \\
\text { - Overland flow routing is calculated by combined continuity equation and Manning's equation. } \\
\text { - } \text { Channel flow routing is variable storage routing method (Williams, 1969). } \\
\text { - Percolation is based on capacity-based approach by considering the impacts of ponded lower layer (Savabi and Williams, 1995). } \\
\text { - Interflow is calculated based on kinematic storage model which is used in the SWAT (Sloan et al., 1983). } \\
\text { - Only unconfined aquifer can be considered using similar approach selected in SWAT (Neitsch et al., 2002). }\end{array}$ \\
\hline Sediment & $\begin{array}{l}\text { - Rill and interrill erodibility are separately calculated based on the WEPP approach (Alberts et al., 1995). } \\
\text { - Channel erodibility is calculated based on the simplified rill erodibility approach in WEPP. } \\
\text { - Transport capacity is estimated based on Yalin's equation (Yalin, 1963). } \\
\text { - Sediment routing is considered based on continuity equation (Byne, 2000). }\end{array}$ \\
\hline Pesticide & $\begin{array}{l}\text { - Degradation is based on the first-order kinetics equation by adjusting based on soil temperature and water content (Truman et al., 1998). } \\
\text { - Equilibrium is based on the linear isotherm equation. } \\
\text { - Overland pesticide routing is calculated based on hydrology output and pesticide concentration by linear isotherm equation. } \\
\text { - Pesticide movement in ground water is considered based on distance to a nearest stream segment and average velocity of pesticide movement. } \\
\text { - Pesticide movement by plant uptake, leaching, and interflow are considered. }\end{array}$ \\
\hline Dynamic variable & $\begin{array}{l}\text { - Soil subcomponent predicts hydraulic conductivity, erodibilities for interrill, rill, and channel, critical hydraulic shear for rill and channel (Alberts et } \\
\text { al., 1995); and wetting front capillary potential (Byne, 2000). } \\
\text { - Plant growth subcomponent predicts biomass, Leaf Area Index (LAI), canopy cover and height (Arnold et al., 1995); and root depth (Borg and } \\
\text { Grimes, 1986). } \\
\text { - Residue decomposition subcomponent predicts decomposition rates of flat, buried, and dead root biomasses (Stott et al., 1995). }\end{array}$ \\
\hline
\end{tabular}

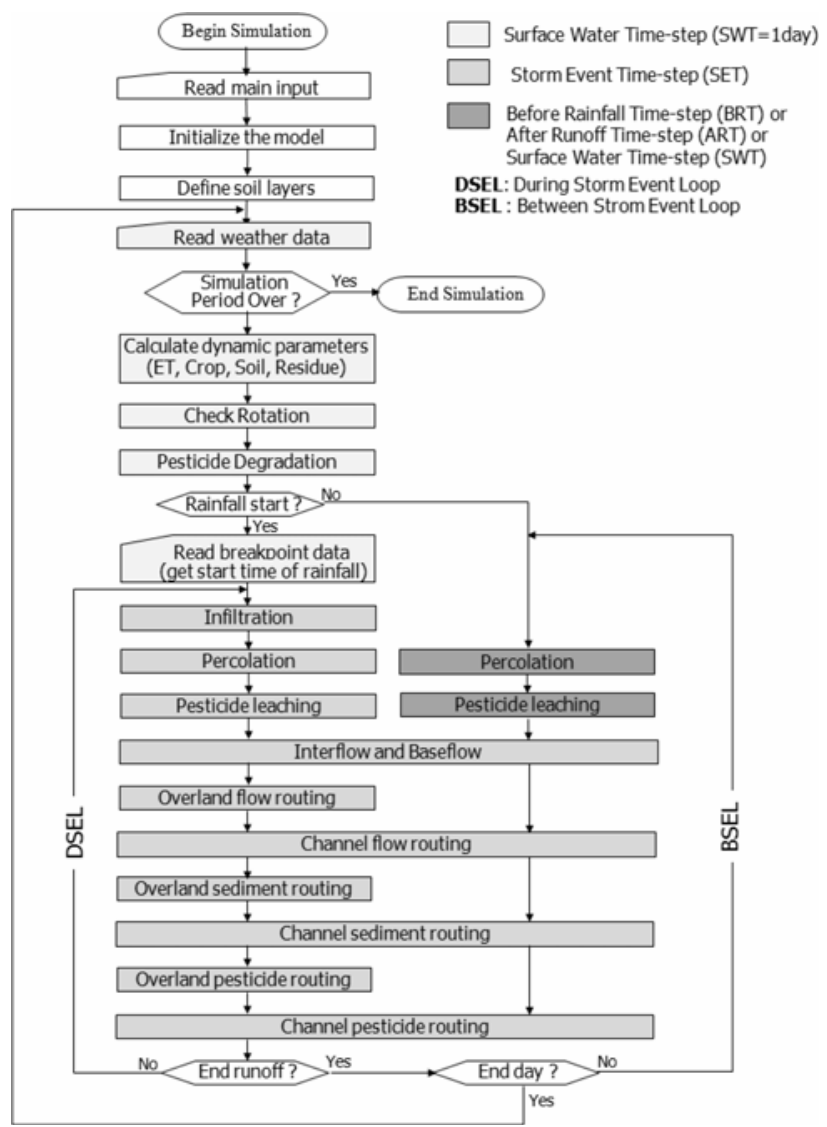

Fig. 1 The flowchart for DANSAT Model and time-steps used for various components ponents and selected time-step for the components are described in Fig. 1. The flowchart consists of two main loops: During Storm Event Loop (DSEL) and Between Storm Event Loop (BSEL). The DSEL of hydrology components predicts water movement during storm events using a user-defined storm event time-step (SET). DSEL contains interception, infiltration, percolation, interflow, baseflow, overland flow, and channel flow sub-components. Between storm events, the water moves in subsurface and channels without any supply of surface runoff from overland areas. BSEL contains percolation, interflow, baseflow, and channel flow routing sub-components. Channel routing related components and subsurface related component such as percolation, pesticide leaching, interflow, and baseflow components are commonly used for both DSEL and BSEL.

DANSAT was applied to two agricultural watersheds in Virginia to evaluate the capability of model for considering temporal and spatial impacts of agricultural land management on hydrology and sediment (Cho and Mostaghimi, 2009a). Temporal and spatial variations in the simulated stream flow were in reasonable agreement with field results while the sediment component showed acceptable agreement only for the watershed where measured stream flow and sediment yield showed better relationship. Field-scale model 
components with a focus on pesticide were evaluated by simulating water, sediment, and pesticide movement both in surface and through the soil profile (Cho and Mostaghimi, 2009c). The model performed well in predicting seasonal and total surface runoff, sediment load, and pesticides loads. Movements of percolated water and pesticides in the soil profile were also well reproduced by the model. Limitations of DANSAT were also derived through the field-scale and watershed-scale evaluations.

\section{A. Hydrology Component}

Hydrology components of DANSAT include interception, evapotranspiration, infiltration and percolation, overland flow, channel flow, interflow, and baseflow components. DANSAT consists of a cell component and a watershedscale component. The cell component uses interception, infiltration, percolation, and evapotranspiration to simulate water and pollutant movement in each single cell. The watershed-scale component routes the water, which are calculated by the cell component, to downstream cells until they reach the watershed outlet. The watershedscale component includes overland flow, channel flow, interflow, and baseflow sub-components. The physicallybased Green-Ampt equation (Green and Ampt, 1911) was used to simulate infiltration considering unsteady rainfall. Soil evaporation and plant transpiration were predicted separately using the Ritchie equation (Ritchie, 1972). The capacity-based percolation subroutine was incorporated to simulate the movement of soil water (Savabi and Williams, 1995). The remaining water, which excesses the field capacity of each soil layer, is percolated down below soil layers until the percolated water reaches the ground water table. A kinematic storage model for lateral subsurface flow (Sloan et al., 1983) was adapted into DANSAT to simulate interflow in subsurface areas. A concept similar to the one used in SWAT (Neitsch et al., 2002) was selected for simulating baseflow. Interflow and ground water inflow, which are simulated by interflow and baseflow components, are added to channel segments as lateral flows for channel routing. Available water in the channel segment is routed to the watershed outlet by the channel routing component using a variable storage routing method, as used by SWAT (Neitsch et al., 2002a).

\section{B. Sediment Component}

Sediment components simulate interrill detachment, rill detachment, channel detachment, transport capacity, overland routing, and channel routing. Physically-based sediment detachment components for overland and channel were adapted. Overland sediment detachment is calculated by separately considering interrill detachment and rill detachment. Available sediments are compared with calculated transport capacity to estimate sediment outflow to the adjacent cells. Yalin's equation was selected to calculate transport capacity for each particle size class. The continuity equation was used to simulate transport of sediment between cells.

\section{Pesticide Component}

The pesticide components simulate pesticide application, degradation, adsorption and desorption, plant uptake, pesticide leaching, pesticide in runoff, interflow, and baseflow. The pesticide component takes into account sediment-bound and dissolved pesticide transport using the capacity-based approach. Pesticide degradation in the soil or foliage is estimated using first-order kinetics, and the degradation rate for a given compound is adjusted based on soil temperature and soil water content. The simple linear equilibrium isotherm equation is used to simulate the interactions between the pesticide chemical and the soil particle surface. Uptake of pesticides by plants was considered as a part of the overall transpiration process. Pesticide movement by interflow was considered based on the amount of water movement and pesticide concentration, which is updated for changes in soil water using the equilibrium isotherm equation. One dimensional transport of pesticide in ground water was calculated based on the distance from a given cell to the nearest channel cell and travel time, which is required for the pesticide peak to reach the nearest stream segment.

\section{Dynamic Variable Component}

Spatially and temporally changing land management practices alter soil, crop, and ground surface characteristics over a watershed and influence the process of infiltration, runoff, sediment detachment and transport, and agricultural 
chemical leaching into ground water. A comprehensive NPS pollution model should take into account the changes in soil, crop, and residue characteristics due to the spatial and temporal changes of BMPs. As a result, soil, plant growth, and residue decomposition components in the WEPP model were slightly modified and incorporated into the DANSAT to consider temporal changes of land management practices. The purpose of soil component is to simulate changes in soil characteristics due to various agricultural managements. The soil component predicts effective hydraulic conductivity and interrill and rill erodibility factors which are used for calculating runoff and soil detachment by hydrology and sediment components, respectively. These are calculated, based on daily variable soil parameters including random roughness, ridge height, and bulk density. Temporal changes in crop variables, such as biomass, leaf area index (LAI), canopy cover, canopy height, root development, and interception, are simulated by the plant growth component. The residue decomposition component predicts decomposition rates of three types of residues such as flat, buried, and dead root biomasses. The three components are interactive with each other. Daily estimated biomass is used to predict the LAI, canopy cover and height, and interception of precipitation. LAI is used in the evapotranspiration component to simulate the extraction of water from multiple soil layers in combination with the simulated root

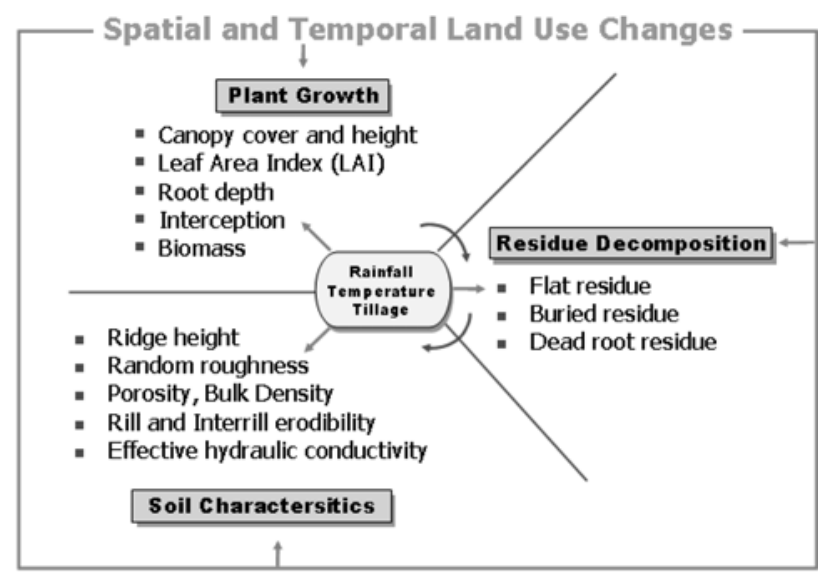

Fig. 2 Schematic representation of the impacts of spatial and temporal land use changes on crop, soil, and residue parameters and relationship among plant, soil, and residue components depth. The simulated canopy height and cover, as well as dead roots and live root biomass, are used to adjust the rill and interrill erodibility factors in the soil component. Predicted random roughness, residue cover, canopy cover, and canopy height are used to simulate daily variable hydraulic conductivity, rill erodibility, and interrill erodibility. A schematic representation of the impacts of spatial and temporal land use changes on crop, soil, and residue parameters and interactive relationship among three components is shown in Fig. 2.

\section{Input File Structures}

Input structure of NPS pollution models should be appropriate for considering temporally and spatially changing BMPs. DANSAT requires three indispensable input files such as weather, break-point rainfall, and main input files. Fig. 3 shows the necessary input files and the data structure of the main input file. Break-point rainfall data is separated from the weather input file. If the model reads one day of weather input and there is a rainfall event on the day, DANSAT reads break-point rainfall data from a separate break-point input file. The structure of main input file should be appropriate for considering temporally and spatially changing BMPs. The hierarchical structure of "physical variable data blocks $\rightarrow$ temporal variable data block (Rotation data block) $\rightarrow$ spatial variable data block (Cell data block)" was used to allow DANSAT consider both spatial and temporal land management practices in detail. Physical data blocks

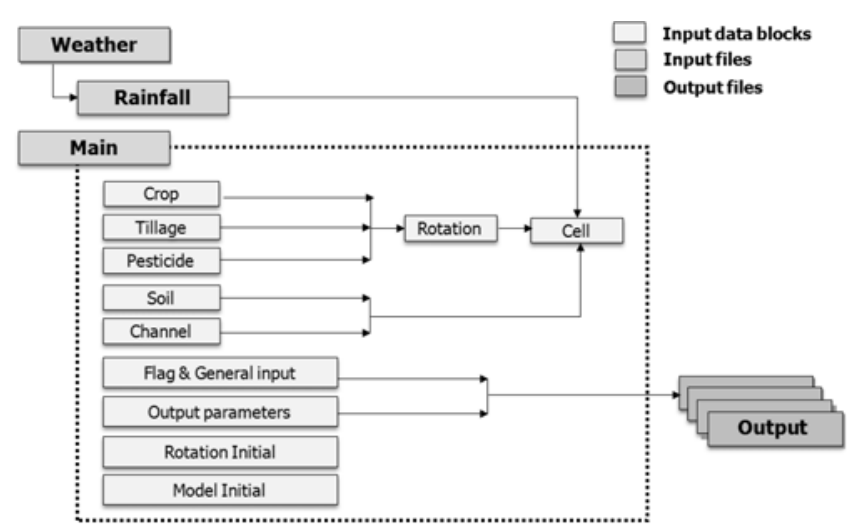

Fig. 3 Input files for DANSAT and the data structure of the main input file 
Table 2 Physical variable data blocks and input parameters used in DANSAT

\begin{tabular}{|c|c|}
\hline Data blocks & Parameter \\
\hline Soil & $\begin{array}{l}\text { - } \text { Bottom depth of each layer }(\mathrm{m}) \\
\text { - Soil water characteristics (Total porosity, Field capacity, Wilting point, Residual water content) } \\
\text { - } \text { Bulk density }\left(\mathrm{mg} / \mathrm{cm}^{3}\right) \\
\text { - Soil texture }(\text { Soil clay content }(\%), \text { Soil sand content }(\%) \text {, Soil silt content }(\%), \text { Soil organic matter content }(\%) \text {, Very fine sand content }(\%), \text { Coarse } \\
\text { - } \text { Sagment content }(\%)) \\
\text { - } \text { Saturated hydraulic conductivity }(\mathrm{m} / \mathrm{h}) \\
\text { Cation exchange capacity }(\mathrm{meq} / \mathrm{kg})\end{array}$ \\
\hline Crop & $\begin{array}{l}\text { - Crop parameter for converting energy to biomass }(\mathrm{kg} / \mathrm{MJ}) \\
\text { - Critical soil water content below which plant growth is subjected to water stress }\left(\mathrm{m}^{3} / \mathrm{m}^{3}\right) \\
\left.\text { - Base temperature (no growth occurs at or below, }{ }^{\circ} \mathrm{C}\right) \text {, Optimum temperature }\left({ }^{\circ} \mathrm{C}\right) \\
\text { - } \text { Amount of the crop's growth period required for the crop to reach full size (NOD: 0-1) } \\
\text { - Maximum Rooting Depth (m), plant canopy height (m), and Leaf Area Index } \\
\text { - Root to shoot ratio (NOD:0-1) } \\
\text { - Parameter for canopy cover and canopy height equation (NOD) } \\
\text { - Fraction of above-ground biomass remaining after senescence } \\
\text { - Fraction of canopy cover remaining after senescence (NOD:0-1) } \\
\text { - Number of days between the beginning and end of leaf drop } \\
\text { - Potential Heat Units to crop maturity }\left({ }^{\circ} \mathrm{C}\right) \\
\text { - Fraction of growing season when leaf area index starts declining } \\
\text { - Parameter for flat residue cover equation }\left(\mathrm{m}^{2} / \mathrm{kg}\right)\end{array}$ \\
\hline Tillage & $\begin{array}{l}\text { - Random roughness immediately after tillage }(\mathrm{m}) \\
\text { - Fraction of soil surface disturbed by the tillage implement } \\
\text { - Ridge height immediately after tillage }(\mathrm{m}) \\
\text { - Ridge interval (m) } \\
\text { - Mean tillage depth associated with each implement (m) }\end{array}$ \\
\hline Pesticide & $\begin{array}{l}\text { - Wash-off fraction } \\
\text { - Foliar residue half-life (days) and Soil half-life (days) } \\
\text { - Partitioning coefficient } \\
\text { - Water solubility (mg/l) } \\
\text { - Plant uptake coefficient }\end{array}$ \\
\hline Stream & $\begin{array}{l}\text { - Channel type parameters } \\
\text { - Channel type (1: Rectangle, 2: Triangle channel) } \\
\text { - Channel Width (m) } \\
\text { - Bank slope of channel type } 2 \text { (Triangle only) } \\
\text { - Manning's n for the channel } \\
\text { - Fraction of Unerodible Channel Soil, or erosion resistant for the type } 1 \text { and Maximum Erodible Depth for the type } 2\end{array}$ \\
\hline
\end{tabular}

Table 3 Temporal variable data block and parameters used in DANSAT

\begin{tabular}{c|l}
\hline Data block & \multicolumn{1}{c}{ Parameter } \\
\hline \hline \multirow{3}{*}{ Rotation } & - Date (month, day, year) \\
& - Agricultural management type (0: Tillage, 1: Planting, 4: Pesticide application, 8: Harvesting) \\
& - Application type for each management (tillage type, crop type, pesticide type) \\
& - Variables (pesticide application: application rate (kg/ha), harvesting: percent cover of residue after harvest (\%)) \\
\hline
\end{tabular}

define physical properties of crop, soil, pesticide, and tillage applications. Physically-based model inputs are useful for reflecting temporal changes in characteristics of soil, crop, and residue cover and the temporal variations should be incorporated into spatial-scale. Physical parameters are not influenced by any spatially and temporally changing BMPs, therefore, they are not changed during the simulation period. Temporal changes of BMPs in each specific field are considered in the rotation data block by chronically combining different crop planting and harvesting, primary and secondary tillage application, and pesticide applications. Spatial distribution of rotation (land use), soil, and topographic parameters and meteorological input are combined in the cell data block to 
Table 4 Spatial variable data block and parameters used in DANSAT

\begin{tabular}{|c|c|}
\hline Group & Parameter \\
\hline Topographic & $\begin{array}{l}\text { - Surface elevation (m) } \\
\text { - Aspect from north on clockwise (Degree) } \\
\text { - Slope of surface }(\%) \\
\text { - } \text { Channel type number } \\
\text { - Slope of channel }(\%) \\
\text { - } \text { Channel length for channel element } \\
\text { - } \text { Average depth to the ground water table from surface (m) }\end{array}$ \\
\hline Soil & $\begin{array}{l}\text { - Soil numbers (identification) in overland areas } \\
\text { - Soil numbers in channel segments }\end{array}$ \\
\hline Land use & $\begin{array}{l}\text { - Rotation Number, Manning's n for bare soil (0: calculating by model) } \\
\text { - Effective Depth of Interaction for overland element (m) }\end{array}$ \\
\hline Weather & - Rain gauge number \\
\hline
\end{tabular}

account for the placement of BMPs as well as spatial distribution of topographic, meteorological, and soil-related variables. Required physical, temporal, and spatial input parameters are explained in Tables 2, 3, and 4, respectively.

\section{Output Files}

A robust model should be able to provide a variety of output files for analysis of simulation results. Outputs at watershed outlets are necessary for understanding the overall impacts of implemented BMPs on surface hydrology and water quality while vertically and spatially distributed outputs are necessary to analyze the BMP impacts on moisture and pollutants transport in the subsurface. DANSAT creates three different types of output files: 1) outlet output, 2) flux output, and 3) cell-based output. Fig. 4 show available output files for DANSAT and spatial, temporal, and vertical scale for each output type. Outlet output includes daily output and storm event output files which provide runoff, sediment, and pesticide results at multiple user-defined outlet cells. Daily output files provide daily total amount of runoff, sediment load, and pesticide load. The hydrograph and water quality results for each storm event are summarized in the storm-event output files depending on the user-defined frequency of output which should always be greater than the selected modeling time step.

The flux output files provide information about the amount of water and pesticides passing through three interfaces between: 1) ground surface and root zone areas; 2) root zone and intermediate zone areas; and 3) intermediate zone and saturated zone areas. Flux files provide insights into the impacts of BMPs on subsurface regime by showing the spatial distribution of predicted water and pesticide flux in each interface based on user-defined frequency that model results are printed to output files. Flux output based on daily frequency is appropriate for research and model validation purposes and monthly or annual flux output can be used to evaluate the long-term BMP impacts on the subsurface.

Cell-based output provides vertical distribution and time series of soil water content and pesticide concentration in one cell at a daily time-step. Vertical distribution of pesticide concentrations provides information about the pesticide movement from surface through root zone after pesticide application. Consideration of multiple soil layers in root zone depth is necessary to evaluate impacts of different tillage and pesticide application methods on water and pollutant transport. Determination of soil layer depth in the intermediate zone (from the bottom of root zone to the ground water table) is also necessary for simulating water and pesticide movement through the intermediate zone to ground water table. In addition, models with multiple soil layers have the advantages of considering plant uptakes of pesticide and crop evapotranspiration at various crop growth stages in root zone. DANSAT defines multiple soil layers based on two different sources: 1) physical soil layer depth, which is typically derived from soil database (SURRGO), and 2) rotation-based soil layer depths, which are defined by combination of tillage application depths, pesticide application depths, maximum 


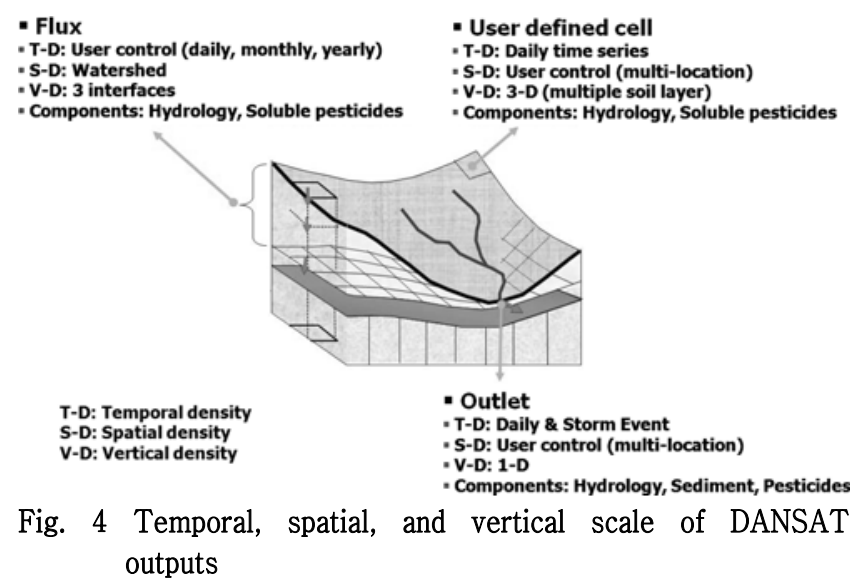

root depths of different crops, and EDI. Thereby, soil layer depths, which are defined based on different soil types and different rotation application depths, are not identical among cells. Time series output provides information on daily changes in water content and pesticide concentration at a specific soil layer throughout the simulation period. Similarly, time series output of pesticide concentration can be used to evaluate the effects of different pesticide application rates, degradation rates, and user-defined transport related parameters on pesticides transport through the soils and to the groundwater.

\section{MODEL INTERFACE}

\section{Selection of a GIS coupling approach}

A user interface is indispensable to a physically-based, distributed parameter, and watershed scale model which requires intensive spatial and temporal input data. Most interfaces, especially interfaces for the distributed parameter models, utilize the GIS functionalities in order to treat intensive spatial data. The three coupling approaches of GIS and models, namely loose, close, and tight couplings (Liao and Tim, 1997) can be subdivided into two groups according to the location of the interface: model-based and GIS-based coupling. The loose coupling has separate user interface for each GIS and model and ASCII or binary files are used to transport data between GIS and model (Fig. 5a and 5b). The close coupling approach uses a single common interface for both GIS and the model. GIS and the model exist independently in spite of the common interface (Fig. 5c and 5d). Tight coupling, which is also referred to the integrated approach, provides common user interface for both GIS and the model. Both the functionality of GIS and processes of model rely on a single system, thus there is no need to transfer data between GIS and model. In tight coupling, GIS and model rely on a single data manager and share data with computer memory rather than ASCII/Binary files (Fig. 5e and 5f).

The loose and close coupling approach have been frequently applied in linking GIS and models because of significant requirements of programming efforts for developing a tightly coupled system (Sui and Maggio, 1999). In addition, GIS-based tight coupling approach may have restrictions in representing detailed hydrologic processes within the selected GIS software. Model-based tight coupling need to have own GIS functionalities within the model interface but the GIS mapping tool may not be comparable to commercial GIS data structures. For both loose and close coupling approaches, GIS-based approach can be dependent on selected GIS software for manipulating spatial data. For example, a number of GISAGNPS interfaces including GRASS-AGNPS (He et al., 1993; Line et al., 1997; Srinivasan and Engel, 1994), Arc/ Info-AGNPS (Liao and Tim, 1997), and Arc/View-AGNPS (He et al., 2001) have been developed for the same model, AGNPS, according to the popular GIS software's such as GRASS, Arc/Info, and Arc/View. Several spatial data manipulation procedures, including watershed and channel network delineation, can be commonly used for different hydrologic models. However, the common GIS functionalities should be repeated within each model interface if GIS functionalities are embedded into a specific model interface within the model-based close coupling approach.

For these reasons, model-based loose coupling method (Fig. 5a), which may be the most realistic method for developing GIS-model interface, was selected for the DANSAT interface. If the GIS functionalities are separated from the interface, this independency will improve the efficiency in developing an interface and provides users with flexibility in selecting not only the GIS software but also the operating system. In this study, spatially variable 


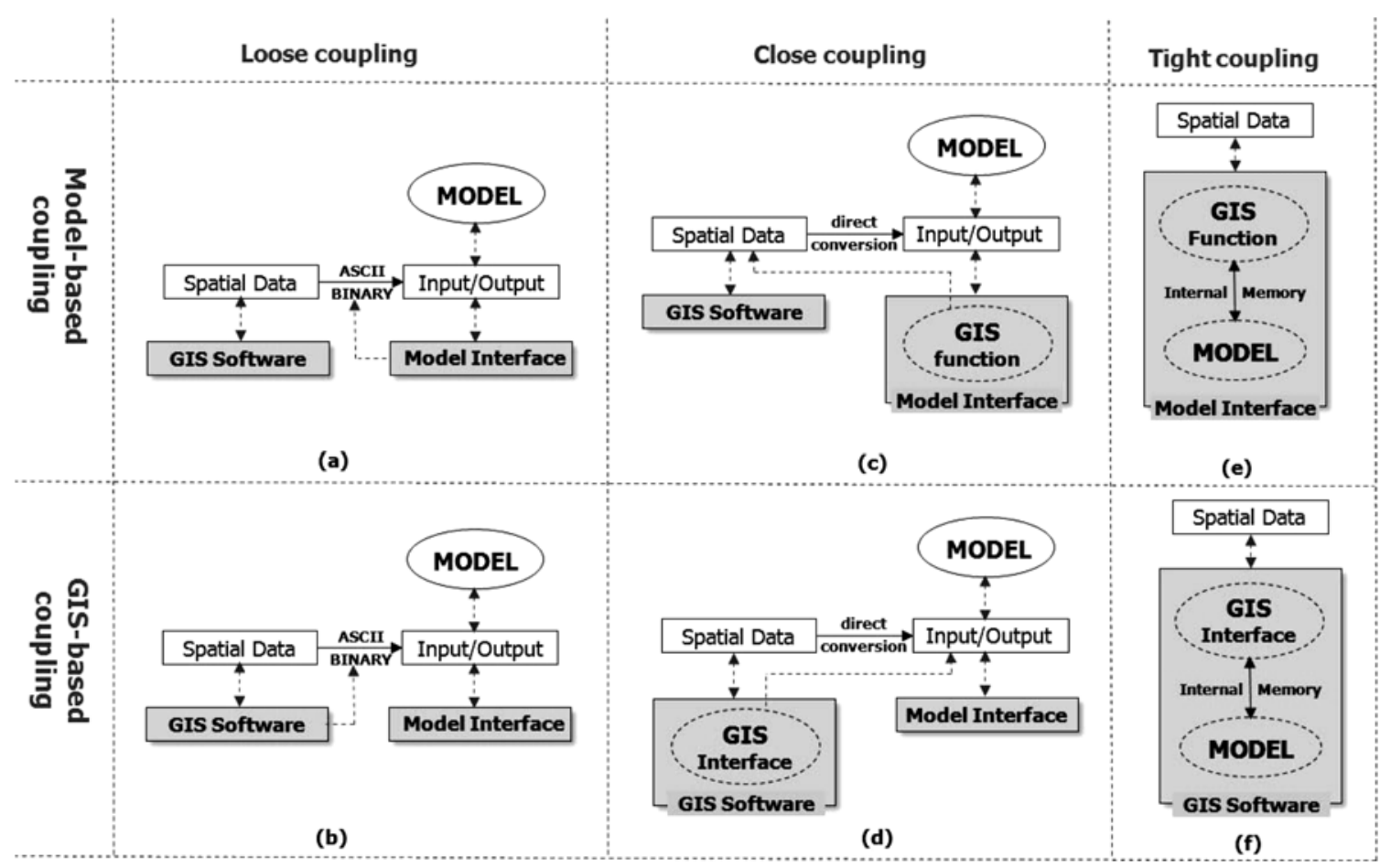

Fig. 5 Alternative approaches used for GIS and model coupling: (a) model-based loose coupling; (b) GIS-based loose coupling; (c) model-based close coupling; (d) GIS-based close coupling; (e) model-based tight coupling; and (f) GIS-based tight coupling

information such as surface elevation, slope, aspect, stream network, soils, rain gauge number and rotation number is extracted from Arc/View ASCII format which can be independently exported by other GIS software as well as Arc/View.

\section{Development of the Interface}

The interface was originally designed to create intensive rainfall input and cell, rotation, and soil data blocks within the main input file. Management and physical information are stored into a predefined database file (Input DB in Fig. 6) which is accessed and manipulated by the interface. The interface uses readily available database files from existing hydrologic models to add input parameters into the input DB. The existing databases include SSURGO from NRCS, crop and tillage databases from WEPP, and pesticide database from GLEAMS. DANSAT requires intensive sub-daily rainfall input date and the interface creates the rainfall input file based on HAS format of the Biological Systems Engineering Dept. at
Virginia Tech (Carr et al., 1988). The spatially distributed parameters are extracted from user-supplied Arc/View ASCII files. The overall data flow for simulating the major components of DASNAT using the model interface are shown in Fig. 6. The interface was developed using Visual Basic and Fig. 7 shows the developed interface windows for generating rainfall input and rotation, soil, and cell data blocks within the main input. Cell menu requires 16 ascii raster files (Arc/View) to create or update cell data block of main input file. DANSAT requires three different groups of soil information for the Soil Data Block within the main input file: particle class size information, general soil information, and soil layer information. General and layer-specific soil parameters for DANSAT can be easily generated from SSURGO using the interface. Rotation data block is one of the most complicated data blocks within the main input file because crop, tillage, and pesticide application information should be combined in this block. The user is able to select agricultural management practice from readily defined crop, pesticide, and list boxes and insert information 


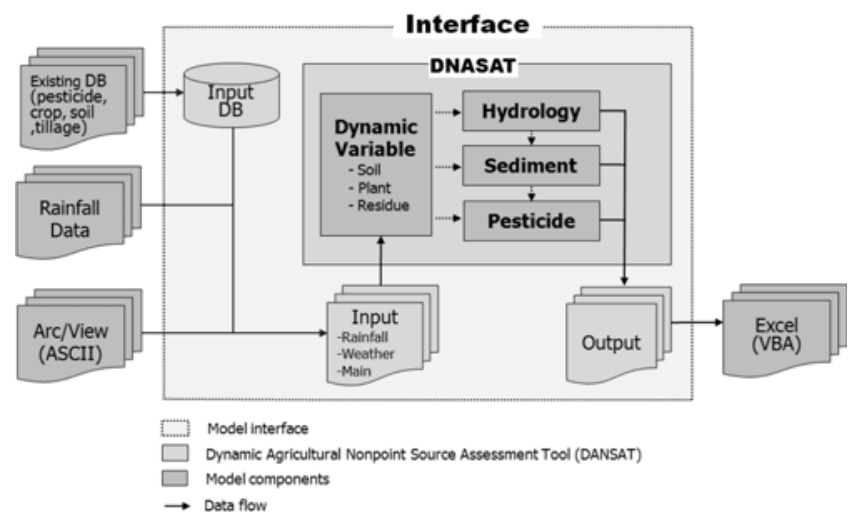

Fig. 6 The overall concept and major functions of the DANSET interface

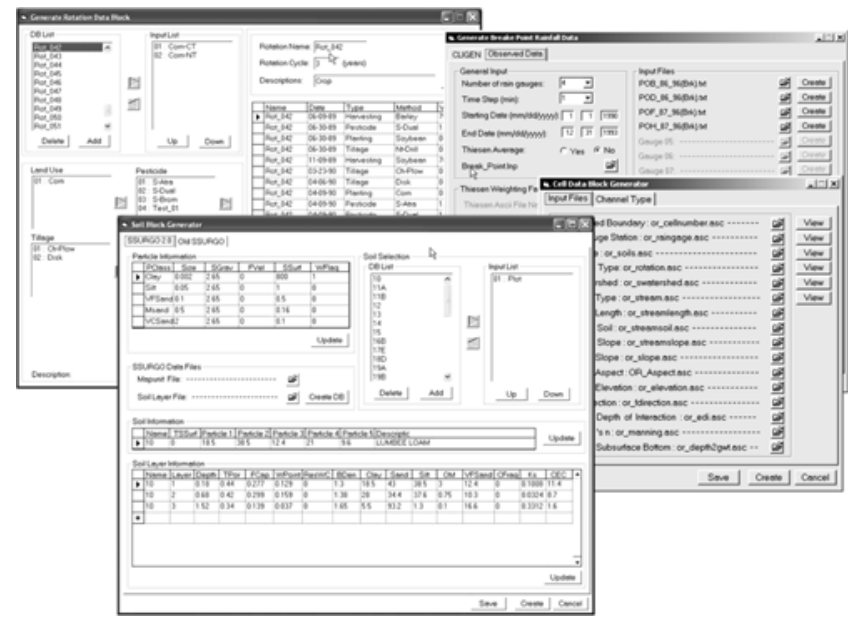

Fig. 7 Interface windows provided by the developed interface for generating rainfall input and soil, cell, and rotation data blocks

based on the predefined order of management practices. Detailed instructions for the interface are provided by Cho (2007).

\section{SUMMARY}

A comprehensive modeling system for BMP assessment, including DANSAT and model interface, were described in this paper. The structure of newly developed model is fully distributed in order to enable consideration of the impacts of spatially changing BMPs on hydrology and water quality. Multiple soil layers were considered to evaluate the vertical impacts of different BMPs, such as tillage and pesticide application methods, on pesticide movement in the root zone.
Simulated processes by DANSAT include: 1) interception, evapotranspiration, infiltration and percolation, overland flow, channel flow, interflow, and baseflow components for hydrology component; 2) interrill detachment, rill detachment, channel detachment, transport capacity, overland routing, and channel routing for sediment component; and 3) pesticide application, degradation, equilibrium, plant uptake, pesticide leaching, pesticide in runoff, interflow, and baseflow for pesticide component. Soil component, plant growth component, and residue decomposition and management component of WEPP were adapted for considering temporal impacts of BMPs on internal parameters within DANSAT. The soil component predicts impacts of agricultural managements on various soil properties such as hydrology-related parameters soil detachment-related parameters. Plant growth component simulates temporal changes in plant characteristics and their impact on the hydrologic and erosion processes. Information on plant related variables such as biomass, leaf area index (LAI), canopy cover, canopy height, root development, and interception are provided to other components for calculating water balance and soil detachment. Decomposition rates of three types of residues such as flat, buried, and dead root biomasses according to different management practices such as tillage and harvesting are internally simulated by the residue decomposition component.

The hierarchical structure of input data blocks was designed for considering both spatial and temporal changes in BMPs. To evaluate the impacts of temporally changing BMPs, the physically-based model parameters for reflecting changes in characteristics of soil, crop, and residue cover during the simulation period was combined in rotation data block. Spatially distributed parameters are then combined in cell data block. DANSAT provides a variety of output files for analysis of spatially and temporally distributed simulation results. Overall impacts of implemented BMPs on surface hydrology and water quality are provided in outputs at watershed outlets. Spatially distributed flux outputs are provided by DANSAT to analyze the BMP impacts on spatial distribution of water and pesticide flux form surface to ground water. Cell-based output provides detail information on temporal changes in soil moisture contents and pesticide concentrations at 
various soil layers and on vertical distribution of soil moisture content and pesticide concentration in the userdefined cells.

Model-based loose coupling was selected for the DANSAT interface in order to improve the efficiency in developing the interface and provides users with flexibility in selecting the GIS software and operating system. The developed interface uses readily available database files from existing hydrologic models and spatially distributed GIS data. The user interface was used for generating intensive input data including rainfall input and rotation, soil, and cell data blocks within the main input. The user is able to select agricultural managements based on the predefined order of management practices.

\section{REFERENCES}

1. Alberts, E. E., M. A. Nearing, M. A. Weltz, L. M. Risse, F. B. Pierson, X. C. Zhang, J. M. Laflen, and J. R. Simanton, 1995. Chapter 7. Soil Component. In: D. C. Flanagan, and M. A. Nearing (Editors), WEPP Technical Documentation, NSERL Report No. 10, West Lafayette, IN.

2. Arnold, J. G., R. Srinivasan, R. S. Muttiah, and J. R. Williams, 1998. Large-area hydrologic modeling and assessment: Part I. Model development. Journal of American Water Resources Association 34(1): 73-89.

3. Arnold, J. G., M. A. Weltz, E. E. Alberts, and D. C. Flanagan, 1995. Chapter 8. Plant Growth Component. In: D. C. Flanagan, and M. A. Nearing (Editors), WEPP Technical Documentation, NSERL Report No. 10, West Lafayette, IN.

4. Bicknell, B. R., J. C. Imhoff, J. L. Kittle, Jr., A. S. Donigian, Jr., and R. C. Johanson, 1993. Hydrologic Simulation Program-FORTRAN (HSPF): User's Manual for Release 10. Report No. EPA/600/R-93/174, U.S. EPA Environmental Research Lab., Athens, GA.

5. Bingner, R. L., and F. D. Theurer, 2001. Topographic factors for RUSLE in the continuous-simulation watershed model for predicting agricultural, non-point source pollutants (AnnAGNPS), In Soil erosion research for the 21st century. Proceedings of the International Symposium, Honolulu, Hawaii, USA, 3-5 January,
2001.

6. Borah, D. K., and M. Bera, 2003. Watershed-scale hydrologic and nonpoint-source pollution models: review of mathematical bases. Transactions of the ASAE 46(6): 1553-1566.

7. Borah, D. K., and M. Bera, 2004. Watershed-scale hydrologic and nonpoint-source pollution models: review of applications. Transactions of the ASAE 47(3): 789-803.

8. Borah, D. K., G. Yagow, A. Saleh, P. L. Barnes, W. Rosenthal, E. C. Krug, and L. M. Hauck, 2006. Sediment and nutrient modeling for TMDL development and implementation. Transactions of the Asabe 49(4): 967-986.

9. Borg, H., and D. W. Grimes, 1986. Depth development of roots with time: an empirical description. Transactions of the ASAE 29(1): 194-197.

10. Bouraoui, F., 1994. Development of a Continuous, Physically-based, Distributed Parameter, Nonpoint Source Model. Ph.D. Thesis, Blacksburg, Virginia: Virginia Polytechnic Institute and State University.

11. Bouraoui, F., I. Braud, and T. A. Dillaha, 2002. ANSWERS: a nonpoint source pollution model for water, sediment and nutrient losses. Water Resources Publications, Colorado, USA, 833-882 pp.

12. Bouraoui, F., and T. A. Dillaha, 1996. ANSWERS2000: runoff and sediment transport model. Journal of Environmental Engineering 122(6): 493-502.

13. Bouraoui, F., and T. A. Dillaha, 2000. ANSWERS2000: non-point-source nutrient planning model. Journal of Environmental Engineering 126(11): 1045-1055.

14. Bouraoui, F., G. Vachaud, R. Haverkamp, and B. Normand, 1997. A distributed physical approach for surface-subsurface water transport modeling in agricultural watersheds. Journal of Hydrology 203: 79-92.

15. Byne, W., 2000. Predicting Sediment Detachment and Channel Scour in the Process-based Planning Model ANSWERS-2000. M.S. Thesis, Blacksburg, Virginia: Virginia Polytechnic Institute and State University.

16. Carr, J. C., P. W. McClellan, J. M. Flagg, S. Mostaghimi, and R. K. Byler, 1988. A Management System for Hydrologic and Water Quality Data-HAS87, Paper No. 88-3007. ASAE, Rapid City, SD. 
17. Cho, J., 2007. A comprehensive modeling approach for BMP impact assessment considering surface and groundwater interaction. Ph.D. Thesis, Blacksburg, Virginia: Virginia Polytechnic Institute and State University.

18. Cho, J., and S. Mostaghimi, 2009a. Dynamic Agricultural Nonpoint Source Assessment Tool (DANSAT): Model Application. Biosystems Engineering (accepted).

19. Cho, J., and S. Mostaghimi, 2009b. Dynamic Agricultural Nonpoint Source Assessment Tool (DANSAT): Model Development. Biosystems Engineering (accepted).

20. Cho, J., and S. Mostaghimi, 2009c. Evaluating cellbased components of DANSAT for predicting surface and subsurface transport of pesticides. Biosystems Engineering (DOI: 10.1016/j.biosystemseng.2009.01.007).

21. Choi, J. Y., and C. M. Shin, 2002. Management of Nonpoint Pollution by Reducing Storm Runoff, Korean Environment Institute, Seoul, Korea.

22. Engel, B. A., R. Srinivasan, J. Arnold, C. Rewerts, and S. J. Brown, 1993. Nonpoint source (NPS) pollution modelling using models integrated with Geographic Information Systems (GIS). Water Science and Technology 28(3-5): 685-690.

23. Green, W. H., and G. Ampt, 1911. Studies of soil physics, Part I. The flow of air and water through soils. Journal of Agricultural Science 4: 1-24.

24. He, C., J. F. Riggs, and Y. T. Kang, 1993. Integration of geographic information systems and a computer model to evaluate impacts of agricultural runoff on water quality. Water Resources Bulletin 29(6): 891900.

25. He, C., C. Shi, C. Yang, and B. P. Agosti, 2001. A windows-based GIS-AGNPS interface. Journal of the American Water Resources Association 37(2): 395406.

26. Liao, H. H., and U. S. Tim, 1997. An interactive modeling environment for non-point source pollution control. Journal of the American Water Resources Association 33(3): 591-603.

27. Line, D. E., S. W. Coffey, and D. L. Osmond, 1997. WATERSHEDSS GRASS-AGNPS model tool. Transactions of the ASAE 40(4): 971-975.

28. Line, D. E., G. D. Jennings, R. A. McLaughlin, D. L.
Osmond, W. A. Harman, L. A. Lombardo, K. L. Tweedy, and J. Spooner, 1999. Nonpoint sources. Water Environment Research 71(5): 1054-1069.

29. Neitsch, S. L., J. G. Arnold, J. R. Kiniry, and J. R. Williams, 2002. Soil and Water Assessment Tool Theoretical Documentation Version 2000. GSWRL Report: 02-01.

30. Novotny, V., and H. Olem, 1994. Water quality prevention, identification, and management of diffuse pollution. Van Nostrand Reinhold, New York, NY.

31. Ogden, F. L., J. Garbrecht, P. A. DeBarry, and L. E. Johnson, 2001. GIS and Distributed Watershed Models. II: Modules, Interfaces, and Models. Journal of Hydrologic Engineering 6(6): 51-523.

32. Priestley, C. H. B., and R. J. Taylor, 1972. On the assessment of surface heat flux and evaporation using large scale parameters. Monthly Weather Review 100: 81-92.

33. Refsgaard, J. C., and J. Knudsen, 1996. Operational validation and intercomparison of different types of hydrological models. Water Resources Research 32(7): 2189-2202.

34. Refsgaard, J. C., and B. Storm, 1995. MIKE SHE. In: V. P. Singh (Editor), Computer Models of Watershed Hydrology. Water Resources Publications, Highlands Ranch, CO., pp. 809-846.

35. Ritchie, J. T., 1972. Model for predicting evaporation from a row crop with incomplete cover. Water Resources Research 8(5): 1204-1213.

36. Savabi, M. R., and J. R. Williams, 1995. Chapter 5. Water Balance and Percolation. In: D. C. Flanagan, and M. A. Nearing (Editors), WEPP Technical Documentation, NSERL Report No. 10, West Lafayette, IN.

37. Sloan, P. G., I. D. Morre, G. B. Coltharp, and J. D. Eigel, 1983. Modeling surface and subsurface stormflow on steeply-sloping forested watersheds. Water Resources Inst. Report 142, Univ. Kentucky, Lexington, KY.

38. Srinivasan, R., and B. A. Engel, 1994. A spatial decision support system for assessing agricultural nonpoint source pollution. Water Resources Bulletin 30(3): 441-452.

39. Stott, D. E., E. E. Alberts, and M. A. Weltz, 1995. 
Chapter 9. Residue Decomposition and Management. In: D. C. Flanagan, and M. A. Nearing (Editors), WEPP Technical Documentation, NSERL Report No. 10, West Lafayette, IN.

40. Sui, D. Z., and R. C. Maggio, 1999. Integrating GIS with hydrological modeling: practices, problems, and prospects. Computers, Environment and Urban Systems 23(1999): 33-51.

41. Tim, U. S., 1996. Emerging technologies for hydrologic and water quality modeling research. Transactions of the ASAE 39(2): 465-475.

42. Truman, C. C., R. A. Leonard, and F. M. Davis, 1998. GLEAMS-TC: a two-compartment model for simulating temperature and soil water content effects on pesticide losses. Soil Science 163(5): 362-373.

43. USEPA, 2000. National Water Quality Inventory: 1998 Report to Congress. Office of Water, Washington, D.C.
44. Veith, T. L., T. M. Nordberg, M. L. Wolf, and T. A. Dillaha, 2000. Questions: a user-friendly interface to ANSWERS-2000, ASAE Annual International Meeting, Milwaukee, Wisconsin, USA.

45. Williams, J. R., 1969. Flood routing with variable travel time or variable storage coefficient. Transaction of the ASAE 12(1): 100-103.

46. Yalin, Y. S., 1963. An expression for bed-load transportation. Journal of the Hydraulics Division, ASCE 89(HY3): 221-250.

47. Zhang, Z., and J. C. Hayes, 1999. An interactive ArcView system for estimating watershed NPS pollution, Paper No. 992245. American Society of Agricultural Engineers, St Joseph, MI. 